\title{
Article \\ Olive Mill and Olive Pomace Evaporation Pond's By-Products: Toxic Level Determination and Role of Indigenous Microbiota in Toxicity Alleviation
}

\author{
Houda Ben Slama ${ }^{1} \mathbb{D}$, Ali Chenari Bouket ${ }^{2,+}{ }^{\mathbb{D}}$, Faizah N. Alenezi ${ }^{3}$, Ameur Khardani ${ }^{1,+}$, Lenka Luptakova ${ }^{4} \mathbb{D}$, \\ Armelle Vallat ${ }^{5}$, Tomasz Oszako ${ }^{6}\left(\mathbb{D}\right.$, Mostafa E. Rateb ${ }^{7}$ (D) and Lassaad Belbahri ${ }^{8, *(D)}$
}

Citation: Slama, H.B.; Chenari Bouket, A.; Alenezi, F.N.; Khardani, A.; Luptakova, L.; Vallat, A.; Oszako,

T.; Rateb, M.E.; Belbahri, L. Olive Mill and Olive Pomace Evaporation Pond's By-Products: Toxic Level Determination and Role of Indigenous Microbiota in Toxicity Alleviation. Appl. Sci. 2021, 11, 5131. https://doi.org/10.3390/app11115131

Academic Editor: Carlos Rico de la Hera

Received: 30 April 2021

Accepted: 29 May 2021

Published: 31 May 2021

Publisher's Note: MDPI stays neutral with regard to jurisdictional claims in published maps and institutional affiliations.

Copyright: (c) 2021 by the authors. Licensee MDPI, Basel, Switzerland. This article is an open access article distributed under the terms and conditions of the Creative Commons Attribution (CC BY) license (https:// creativecommons.org/licenses/by/ $4.0 /)$
1 NextBiotech, 98 Rue Ali Belhouane, Agareb 3030, Tunisia; benslamahouda92@gmail.com (H.B.S.); ameurkhardani@gmail.com (A.K.)

2 Plant Protection Research Department, East Azarbaijan Agricultural and Natural Resources Research and Education Center, Agricultural Research, Education and Extension Organization (AREEO), Tabriz 5355179854, Iran; a.chenari@areeo.ac.ir

3 The Public Authority for Applied Education and Training, Adailiyah 00965, Kuwait; Fn.alenazi@paaet.edu.kw

4 Department of Biology and Genetics, Institute of Biology, Zoology and Radiobiology, University of Veterinary Medicine and Pharmacy in Košice, 04181 Kosice, Slovakia; lenka.luptakova@uvlf.sk

5 Neuchatel Platform of Analytical Chemistry, Institute of Chemistry, University of Neuchâtel, 2000 Neuchâtel, Switzerland; armelle.vallat@unine.ch

6 Department of Forest Protection of the Forest Research Institute in Sekocin Stary, 05-090 Raszyn, Poland; T.Oszako@ibles.waw.pl

7 School of Computing, Engineering \& Physical Sciences, University of the West of Scotland, Paisley PA1 2BE, UK; Mostafa.Rateb@uws.ac.uk

8 Laboratory of Soil Biology, University of Neuchatel, 2000 Neuchatel, Switzerland

* Correspondence: lassaad.belbahri@unine.ch

+ Both coauthors equally cooperated in this paper.

\begin{abstract}
Diverse vegetable oils are extracted from oleagenic trees and plants all over the world. In particular, olive oil represents a strategic socio-economic branch in the Mediterranean countries. These countries use either two or three-phase olive oil extraction systems. In this work, we focus on the by-products from three-phase olive oil extraction, which are the liquid olive mill wastewater $(\mathrm{OMW})$ and the solid olive mill pomace (OMP) rejected in evaporative ponds. The disposal of this recalcitrant waste poses environmental problems such as the death of different species of insects and animals. In-depth ICP-OES analysis of the heavy metal composition of OMW and OMP revealed the presence of many metals ranging from non-toxic to highly toxic. The LC-HRMS characterization of these by-products indicated the presence of several secondary metabolites harmful to humans or to the environment. Thus, we aimed to identify OMW and OMP indigenous microbiota through metagenomics. The bacterial population was dominated by the Acetobacter (49.7\%), Gluconobacter $(17.3 \%)$, Gortzia $(13.7 \%)$ and Nardonalla $(5.3 \%)$ genera. The most abundant fungal genera were Nakazawaea, Saccharomyces, Lachancea and Candida. These microbial genera are responsible for OMW, OMP and soil toxicity alleviation.
\end{abstract}

Keywords: OMW; OMP; evaporation pond; heavy metals; LC-HRMS; metagenomics; indigenous microbiota; toxicity alleviation

\section{Introduction}

Vegetable oils are a staple food for all countries worldwide. They are extracted from multiple sources such as olive oil, palm oil, coconut oil, sunflower oil, canola oil, soybean oil, peanut oil, cottonseed oil, corn oil, argan oil and many more. Particularly, olive oil is considered one of the most versatile and healthy oils in terms of consumption as a food product. Olive oil extraction occurs in either two- or three-phase systems. The two-phase 
extraction process generates the olive oil and olive mill pomace (OMP), also called 'alperujo' in Spanish. This method helps in saving water discharge [1,2]. The three-phase extraction process produces the olive oil and two by-products; a liquid olive mill wastewater (OMW) and a solid olive mill pomace (OMP) [3,4].

Olive oil production is centered in the Mediterranean region including Spain, Italy, Greece and Tunisia, which are the major olive oil producers worldwide, accounting for $97 \%$ of the global market $[5,6]$. Particularly, Tunisia provides $6 \%$ of the world's olive oil production, it occupies the 4th position worldwide and the 1st position in the north African countries with $60 \%$ production [6]. El-Bassi et al. [7] mentioned that Tunisia produces $770.000 \mathrm{~m}^{3}$ /year OMW and 550,000 tons/year of OMP by itself. OMW is a liquid discharge fraction containing water $(\geq 90 \%)$ and multiple organic and inorganic compounds. OMP is the solid discharge fraction which is mainly composed of olive pulp, seed and skin [8]. These by-products constitute a potential danger to the environment, plants and living organisms in all olive oil-producing countries $[7,9,10]$.

The Mediterranean olive oil industries generate huge amounts of OMW and OMP attaining about 30 million $\mathrm{m}^{3}$ discharges per year [9,11], with an average of 0.5 to $1.5 \mathrm{~m}^{3} /$ ton of olive $[12,13]$. OMW characteristics vary according to the geographic and climatic change, the olive cultivar, the fruit quality, the extraction process and the use of chemical fertilizers [13,14]. Overall, OMW features acidic $\mathrm{pH}$, high-sodium content, blackish-purple color, and distinct smell due to its high polyphenols, polyalcohols, and carbohydrates content [15-18].

Olive mill effluents are frequently discharged in the environment into uncontrolled evaporation ponds. Several studies have proved their high concentrations in toxic waste matters (heavy metals, volatile acids, polyphenols and long-chain fatty acids) leading to foul odors release and several harmful effects to the ecosystem such as soil, water, plants, animals, insects and microorganisms [19-21]. The long term disposal of OMW in the open evaporation ponds cause the transformation of the disposed by-products from a liquid to a solid more toxic form. Recalcitrant compounds either concentrate in a dry sludge or infiltrate inside the soil [22]. For that reason, several treatments have been implemented such as the biological, physicochemical, thermochemical methods or the integration of the above-mentioned methods to ensure better results $[18,23,24]$. The role of the indigenous microbial communities in the bioremediation of OMW has been extensively studied [25,26]. These microbes could alleviate, remove or bio-transform toxic compounds from the OMW by-products $[25,27]$.

This paper reports the environmental threat of uncontrolled OMW and OMP disposal in evaporation ponds, as well as an in-depth study of the OMW and OMP heavy metals and secondary metabolites composition. Lastly, the indigenous microbial diversity in the OMW was extensively monitored to investigate its role in alleviating the toxicity of the evaporation ponds.

\section{Materials and Methods}

\subsection{Sampling Site Description}

OMW and OMP by-products originate from three-phase olive oil extraction mills. Samples were collected in 2018 from two evaporation ponds located in Agareb (Figure 1a) and Cherarda (Figure 1d), belonging to the governorates of Sfax and Kairouan in Tunisia, respectively (Figure 1, Table 1).

This study involves a total of fourteen samples (Table 1) divided into: thirteen OMW samples comprising five samples collected from the evaporation pond of Cherarda, seven samples from the evaporation pond of Agareb, and one sample collected from soil mixed with dried OMW and deposited in a huge pile near to the evaporation pond of Agareb (MA). It was further used for OMW metagenomic analysis of the indigenous microbiota (Table 1, Figure 1b). The 14th olive mill pomace (OMP) sample was collected from an olive oil industry and used for further tests. 


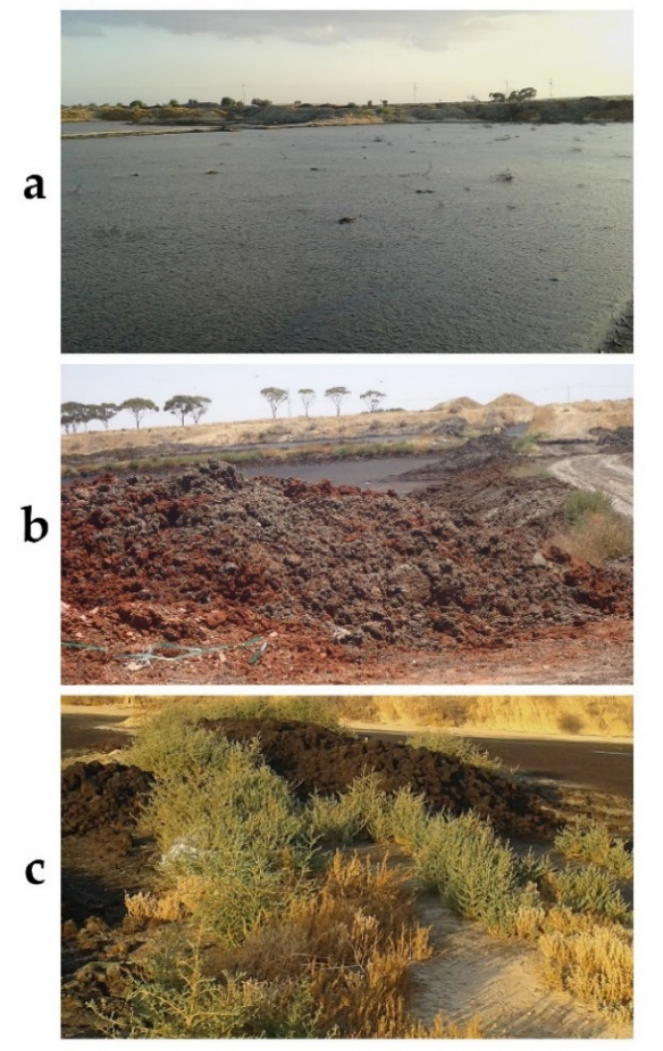

Agareb

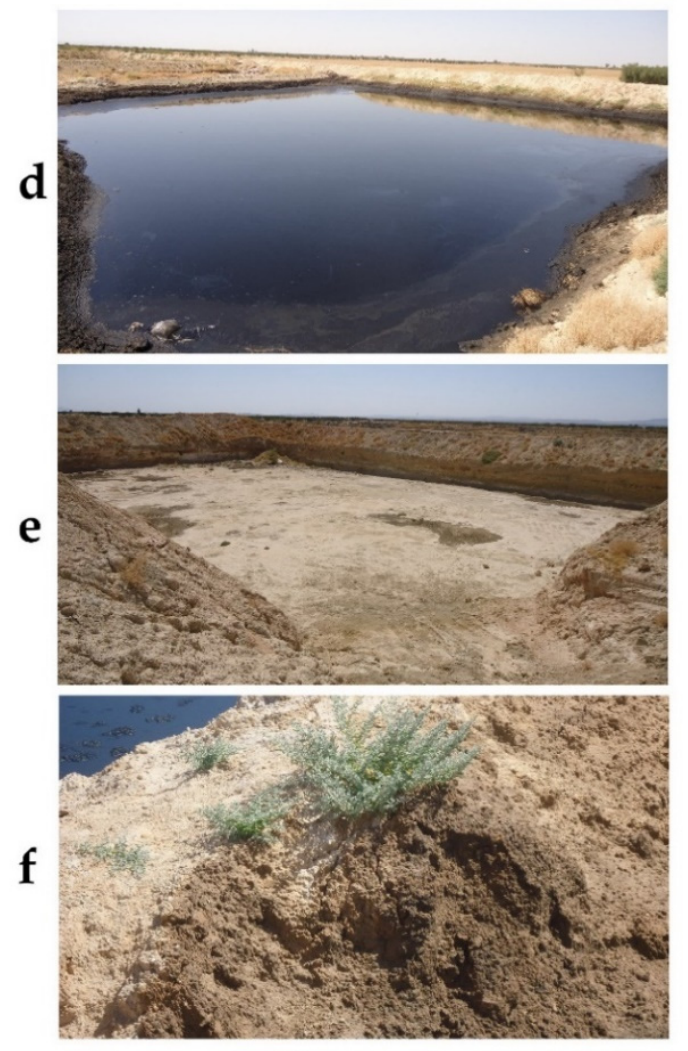

Cherarda

Figure 1. (a,d) Evaporation ponds situated in Agareb and Cherarda, respectively. (b) Pile of soil mixed with dried OMW in Agareb. (e) Newly established evaporation pond in Cherarda. (c,f) Atriplex plants growing in the vicinity of the evaporation ponds of Agareb and Cherarda, respectively.

Table 1. Description of the sampling sites of the evaporation ponds of Agareb and Cherarda.

\begin{tabular}{|c|c|c|}
\hline Samples Codes & Description & Metagenomique \\
\hline A1 & Sample collected from contaminated area around OMW evaporation pond in Agareb & - \\
\hline A2 & $\begin{array}{l}\text { Sample collected from the vicinity of evaporation pond of Agareb with lower level of } \\
\text { contamination }\end{array}$ & - \\
\hline $\mathrm{A} 3$ & $\begin{array}{l}\text { Sample collected outside of the evaporation pond of Agareb with no sign of } \\
\text { contamination (control) }\end{array}$ & - \\
\hline A4 & Sample collected from the center of dried evaporation pond of Agareb & - \\
\hline A5 & $\begin{array}{l}\text { OMW sample collected from the center of dried evaporation pond of Agareb but not fully } \\
\text { dried still wet }\end{array}$ & - \\
\hline MA & Sample collected from soil with dried OMW and deposited in huge piles in Agareb & + \\
\hline $\mathrm{C} 1$ & Sample collected from contaminated area around OMW evaporation pond in Cherarda & - \\
\hline $\mathrm{C} 2$ & $\begin{array}{l}\text { Sample collected from the vicinity of evaporation pond of Cherarda with lower level of } \\
\text { contamination }\end{array}$ & - \\
\hline $\mathrm{C} 3$ & $\begin{array}{l}\text { Sample collected outside of the evaporation pond of Cherarda with no sign of } \\
\text { contamination (control) }\end{array}$ & - \\
\hline $\mathrm{C} 4$ & Sample collected from the center of a completely dried out evaporation pond of Cherarda & - \\
\hline C5 & $\begin{array}{l}\text { Sample collected from the center of a completely dried out evaporation pond of Cherarda } \\
\text { after removal of the dried out residue }\end{array}$ & - \\
\hline
\end{tabular}


Table 1. Cont.

\begin{tabular}{|c|c|c|}
\hline Samples Codes & Description & Metagenomique \\
\hline C6 & $\begin{array}{l}\text { Sample collected from the center of a completely dried out evaporation pond of Cherarda } \\
\text { after digging } 20 \mathrm{~cm} \text { deep }\end{array}$ & - \\
\hline $\mathrm{C} 7$ & $\begin{array}{l}\text { Sample collected from the center of a completely dried out evaporation pond of Cherarda } \\
\text { after digging } 50 \mathrm{~cm} \text { deep }\end{array}$ & - \\
\hline OMP & Olive Mill Pomace sample collected from an olive oil industry & + \\
\hline
\end{tabular}

Briefly, A3 and C3 were the control OMW samples of soil collected from the outside of the evaporation ponds. These samples have no sign of contamination. The remaining samples were taken from contrasting spots situated within (A4, A5, C4 and C5), in the vicinity (A2 and $\mathrm{C} 2$ ) or around ( $\mathrm{A} 1$ and $\mathrm{C} 1$ ) the 2 evaporation ponds, or even after digging $20 \mathrm{~cm}$ (C6) and $50 \mathrm{~cm}$ (C7) deep from the center of a completely dried evaporation pond as clearly shown in Table 1 and Figure 2. One additional sample of OMP was collected from an olive oil industry in Sfax (Table 1). Lastly, we have perceived two plants belonging to the Atriplex genus (Figure 1c,f) being able to grow in the vicinity of the two evaporation ponds.
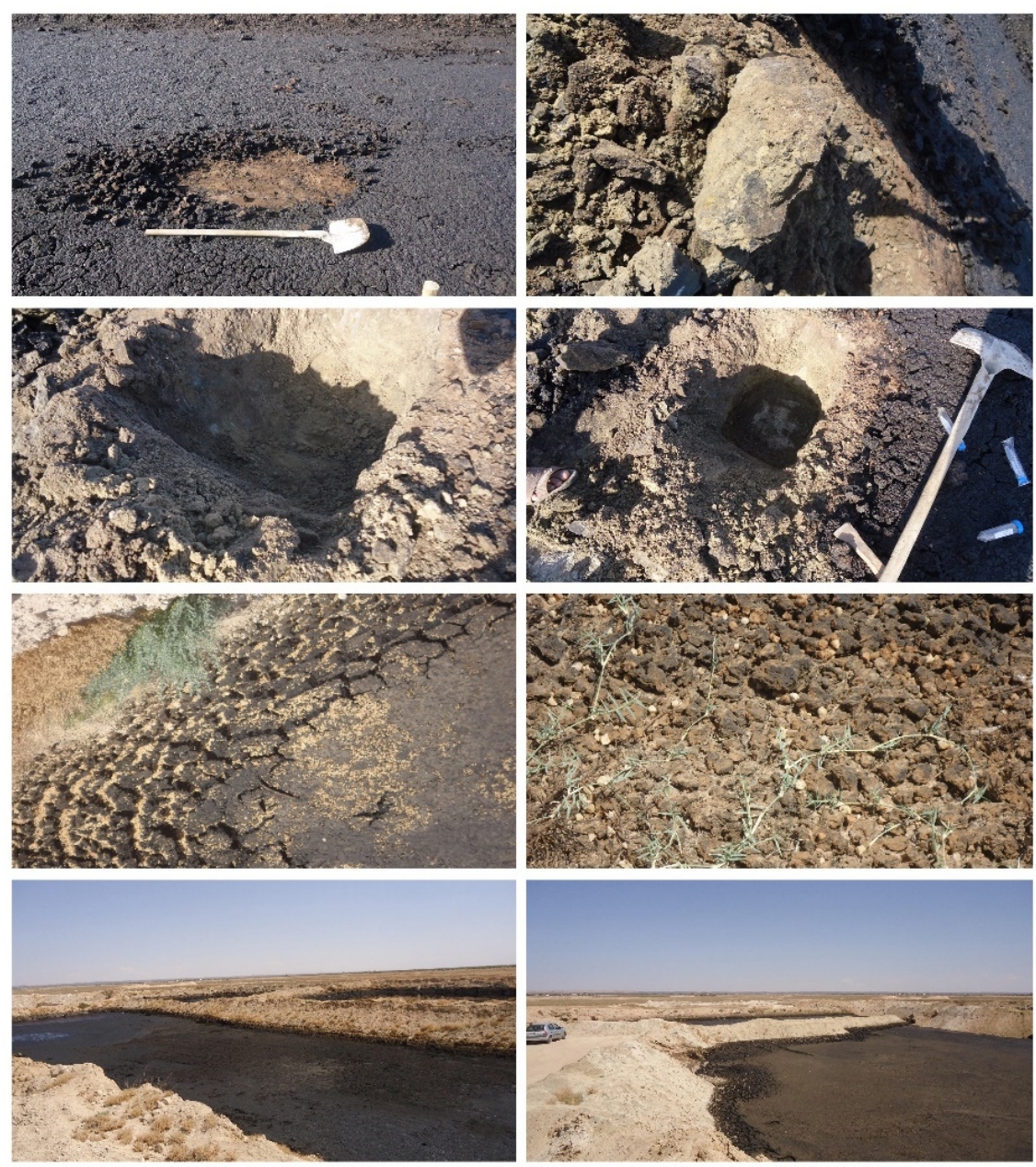

Figure 2. Sampling process of OMW from several spots within, in the vicinity, around, or after digging in the evaporation ponds of Agareb and Cherarda.

2.2. Heavy Metal Analysis of OMW Samples Using Inductively Coupled Plasma Optical Emission Spectrometry (ICP-OES)

Eleven OMW samples (A1, A2, A3, A4, A5, C1, C2, C3, C5, C6 and C7) were analyzed using the ICP-OES method to determine their composition in heavy metals. Samples 
preparation started with a drying step at a temperature of $60^{\circ} \mathrm{C}$ followed by a mashing step until obtaining a smooth texture. Then, elements digestion/extraction was obtained using $65 \% \mathrm{HNO}_{3}$ (Suprapur ${ }^{\circledR}$, Merck KGaA, Germany) for $48 \mathrm{~h}$. Lastly, samples were diluted 100 times by weighing. All samples were analyzed using an ICP-OES (OPTIMA 2100 DV) from Perkin Elmer with AS-93 plus autosampler. The calibration solution contained $2 \%$ $\mathrm{HNO}_{3} \_$MiliQ water $(18 \Omega)$. The detailed protocol was described by Mefteh et al. [28].

\subsection{Liquid Chromatography-High-Resolution Mass Spectrometry (LC-HRMS) Analysis of OMW and OMP Extracted Samples}

The thirteen OMW samples in addition to the OMP sample (10 mL each) were extracted by shaking with $10 \mathrm{~mL}$ ethyl acetate (X2), and the combined ethyl acetate extract for each sample was evaporated under reduced pressure to obtain the total organic extract. Each extract was then re-dissolved in $50 \%$ aqueous methanol to produce $1 \mathrm{mg} / \mathrm{mL}$ final concentration which was then analyzed using LC-HRMS, data were collected on a Thermo Instruments ESI-MS system (LTQ XL/LTQ Orbitrap Discovery, UK) connected to a Thermo Instruments HPLC system (Accela PDA detector, Accela PDA autosampler and Accela Pump). The analyses were executed on a reversed-phase column (Pursuit XRs ULTRA $2.8, \mathrm{C} 18,100 \times 2 \mathrm{~mm}$, Agilent Technologies, UK). Sample injection volume was $20 \mu \mathrm{L}$ at $30{ }^{\circ} \mathrm{C}$ temperature. Mobile phase A contained $0.1 \%$ formic acid in water and mobile phase $\mathrm{B}$ contained $0.1 \%$ formic acid in $\mathrm{MeOH}$. Gradient HPLC acquisition was performed at $1 \mathrm{~mL} / \mathrm{min}$ flow rate starting with $100 \%$ solvent A with gradual increase of solvent $B$ till reaching $100 \%$ over $20 \mathrm{~min}$, followed by additional $5 \mathrm{~min}$ using $100 \%$ of solvent B [29]. LC-HRESIMS of all samples was conducted using XCalibur 3.0 and allowing for $\mathrm{M}+\mathrm{H} / \mathrm{M}$ + Na adduct. The suggested compound dereplication and identification was conducted based on the generated molecular formulae and isotope patterns compared to Dictionary of Natural Products (DNP 23.1, 2015 on DVD) and Reaxys online database.

\subsection{Microbial DNA Extraction from OMW and OMP Samples, PCR Amplification and Metagenomics Analysis of Uncultivable Bacteria and Fungi}

The MA sample collected from soil mixed with dried OMW and deposited in a huge pile and the OMP sample, were used for the metagenomics analysis of uncultivable bacteria and fungi (Table 1). The detailed protocol of metagenomics extraction was described by Mefteh et al. [28]. In brief, genomic DNA was extracted via the UltraClean ${ }^{\circledR}$ Microbial DNA Isolation Kit (QIAGEN, Basel, Switzerland) according to manufacturer instructions. DNA was then used for 16S-rDNA PCR amplification using a Biometra T-one thermal cycler (Labgene, Chatel-Saint-Denis, Switzerland). Metagenomics analysis was achieved by using the PICRUSt tool which helps in predicting the marker gene functions based on the sequence analogy with the reference genome [30]. It was applied to predict the functions of the bacterial populations of OMW.

\section{Results}

\subsection{Effects of the Disposal of OMW in the Evaporative Ponds on the Existing Fauna and Flora}

Figure $1 \mathrm{c}, \mathrm{f}$ belong represent only one plant species growing in the vicinity of the evaporation ponds of Agareb and Cherarda. They belong to the halophytic genus Atriplex.

Figure 3 clearly shows the extremely dangerous impact of the uncontrolled discharge of OMW in evaporation ponds. The skeletons of multiple insects (dragonflies and bugs) and animals (rats, hedgehogs and multiple species of birds) are dispersed all over the ponds of Agareb and Cherarda. Birds were the most threatened animals because of the camouflage created from the reflection of the sky on the evaporation pond, making it seems like water. The oily texture of the OMW hinders the movements of animals and traps them inside the pond engendering their subsequent death (Figure 3). 

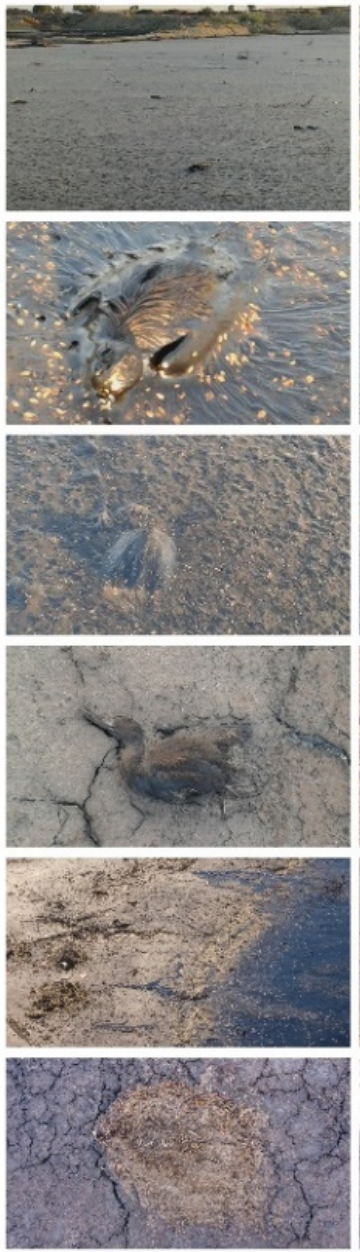
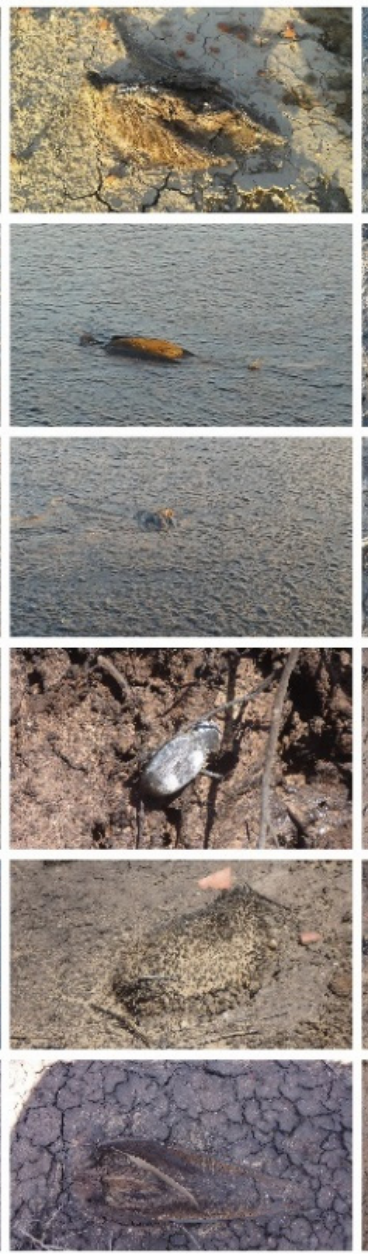
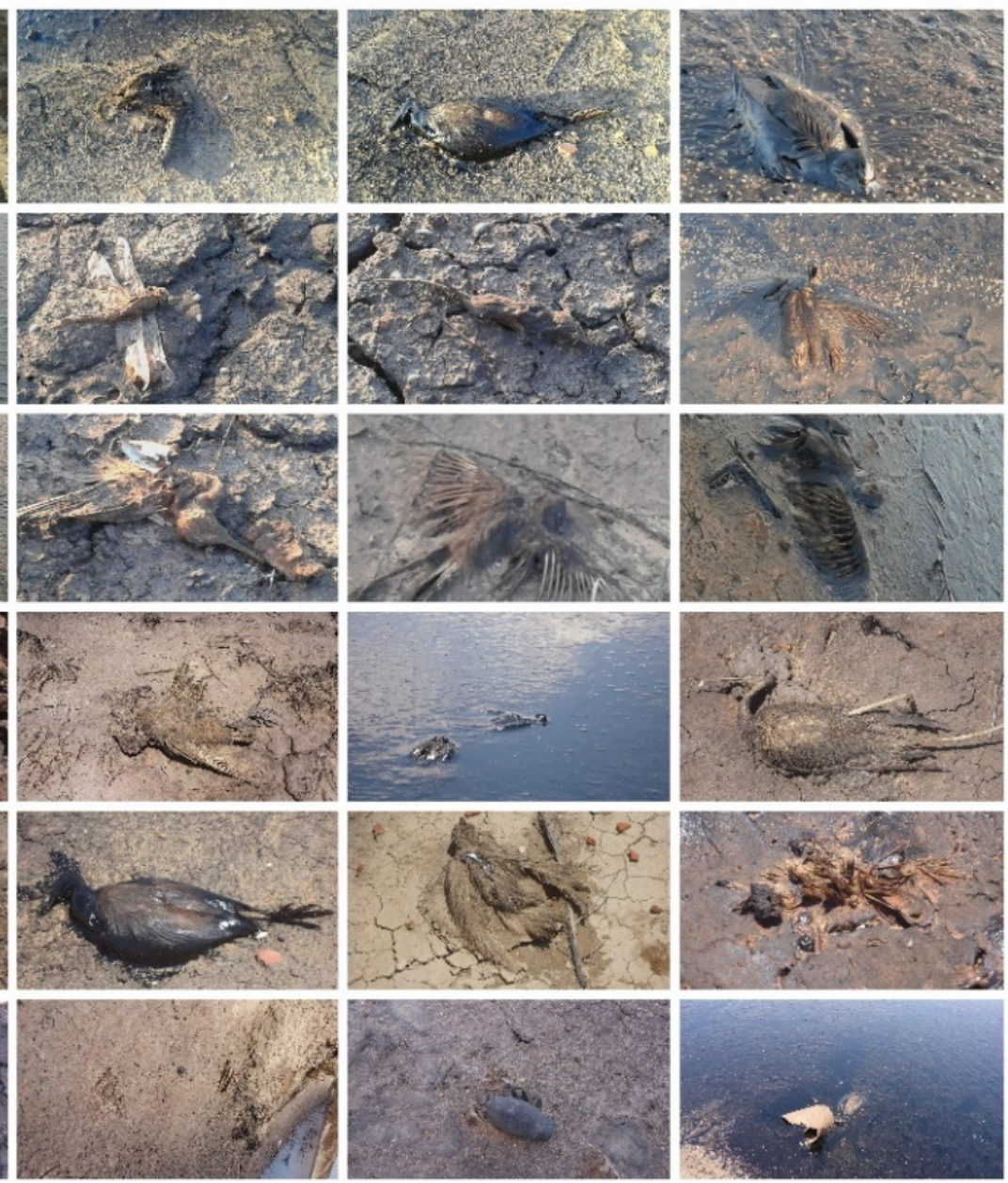

Figure 3. Pictures showing skeletons of multiple species of insects and animals dispersed all over and in the vicinity of the evaporation ponds of Agareb and Cherarda.

\subsection{Heavy Metals Concentrations in OMW Samples}

Eleven samples were collected from different spots located within and surrounding OMW evaporation ponds localized in the regions of Cherarda and Agareb (Figure 4). Both $\mathrm{C} 3$ and $\mathrm{A} 3$ are the control spots, they represent samples collected outside the evaporation pond with no signs of contamination in the regions of Cherarda and Agareb, respectively. The above mentioned samples were tested to determine their heavy metals (HMs) composition. Results presented in Figure 4 were divided into 4 groups based on the HMs concentrations and presence or absence in the sample: (i) the most abundant metals were Calcium (Ca), Potassium (K), Aluminum (Al), Iron (Fe), Magnesium (Mg), Sodium ( $\mathrm{Na}$ ) and Strontium (Sr), (ii) the less abundant metals were Manganese (Mn), Barium (Ba), Zinc $(\mathrm{Zn})$, Rubidium $(\mathrm{Rb})$, Lithium $(\mathrm{Li})$, Chromium $(\mathrm{Cr})$, Copper $(\mathrm{Cu})$, Nickel $(\mathrm{Ni})$, Arsenic (As), Cobalt (Co), Led ( $\mathrm{Pb}$ ) and Tin (Sn), (iii) metals found in only one sample each were Silver (Ag) and Selenium (Se). Ag and Se exist in the sample collected from the center of dried evaporation pond (A4) and the sample collected from the center of the nearly dried evaporation pond (A5), respectively. (iv) lastly metals not detected in either OMW or OMP samples were Cadmium (Cd), Mercury (Hg) and Molybdenum (Mo) (Figure 4). 


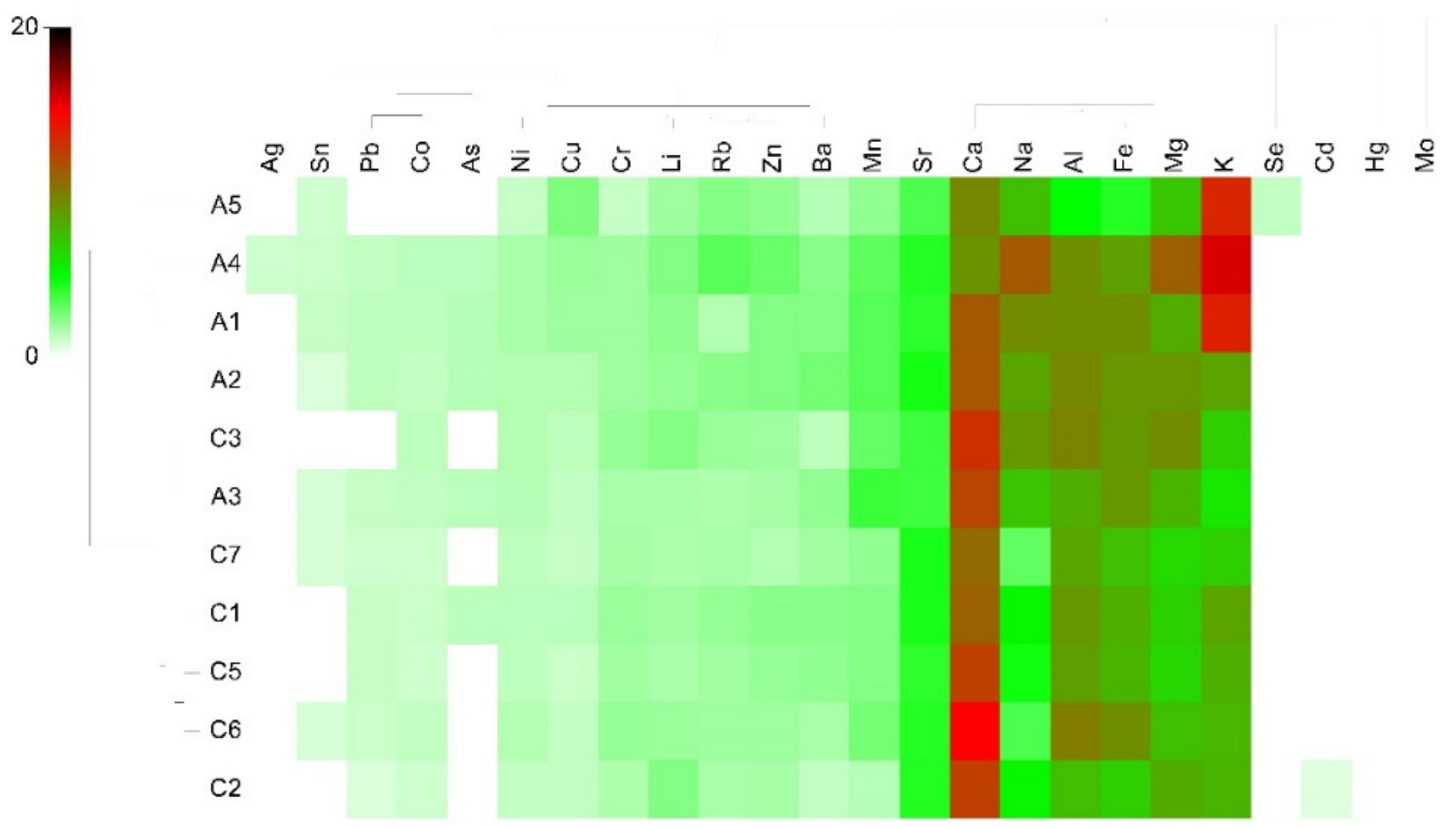

Figure 4. Heat map resulting from ICP-OES analysis and describing heavy metal composition of 11 samples (A1, A2, A3, A4, A5, C1, C2, C3, C5, C6 and C7) collected from different spots situated within and surrounding OMW evaporation ponds of Agareb and Cherarda. (Original data (Table S3) unit is 'ppm' but was transformed by Primer-e program with Euclidean similarity and forth root transformation during heat-map producing).

\subsection{LC-HRMS Analysis of Secondary Metabolites in OMW and OMP}

LC-HRMS analysis of OMW and OMP samples allowed us to detect 46 (Supplementary Table S1) and 69 (Supplementary Table S2) secondary metabolites belonging to different chemical classes, mainly phenolics, terpenoids, and alkaloids. They include metabolites having several biotechnological functions and other metabolites with no reported activities.

Other than that, multiple metabolites were reported to be harmful to humans such as gallic acid, cafeic acid, scoparone, rutin, esculin, apigenin, secologanoside, oleaceran, stigmasterol, apigenin 7-O-D-glucoside and hydroxypinoresinol 4"-O-methyl ether. Additionally, two secondary metabolites named ferulic acid and maslinic acid were reported to be toxic to the environment.

3.4. Genus Level and Metagenomics Analysis of Indigenous Bacterial Communities in OMW and OMP Samples

The Bar Chart (Figure 5a) presents the bacterial genera within the OMP and OMW. Results showed a remarkable difference in the bacterial genera distribution and diversification within the tested samples. The metagenomics analysis of OMP display Acetobacter as the most abundant genus (49.7\%), followed by Gluconobacter (17.36\%), Gortzia (13.77\%) and Nardonalla (5.38\%) genera. However, the OMW sample was massively dominated by Prevotella (82.8\%) succeeded by Spiroplasma (6.75\%), Olsenella (2.73\%) and Lactobacillus $(2.16 \%)$ genera (Figure $5 \mathrm{a})$. The heat map in Figure $5 \mathrm{~b}$ contains the bacterial genus level of OMW with both Prevotella and Spiroplasma being the most abundant genera and in OMP with Acetobacter as the most abundant genus. Furthermore, the bacterial genera within the OMW were far more abundant than those existing in OMP. Six bacterial genera named Acetobacter, Gluconobacter, Fusobacterium, Catenibacterium, Lactobacillus and Prevotella existed in common between OMW and OMP samples (Figure 5b). 


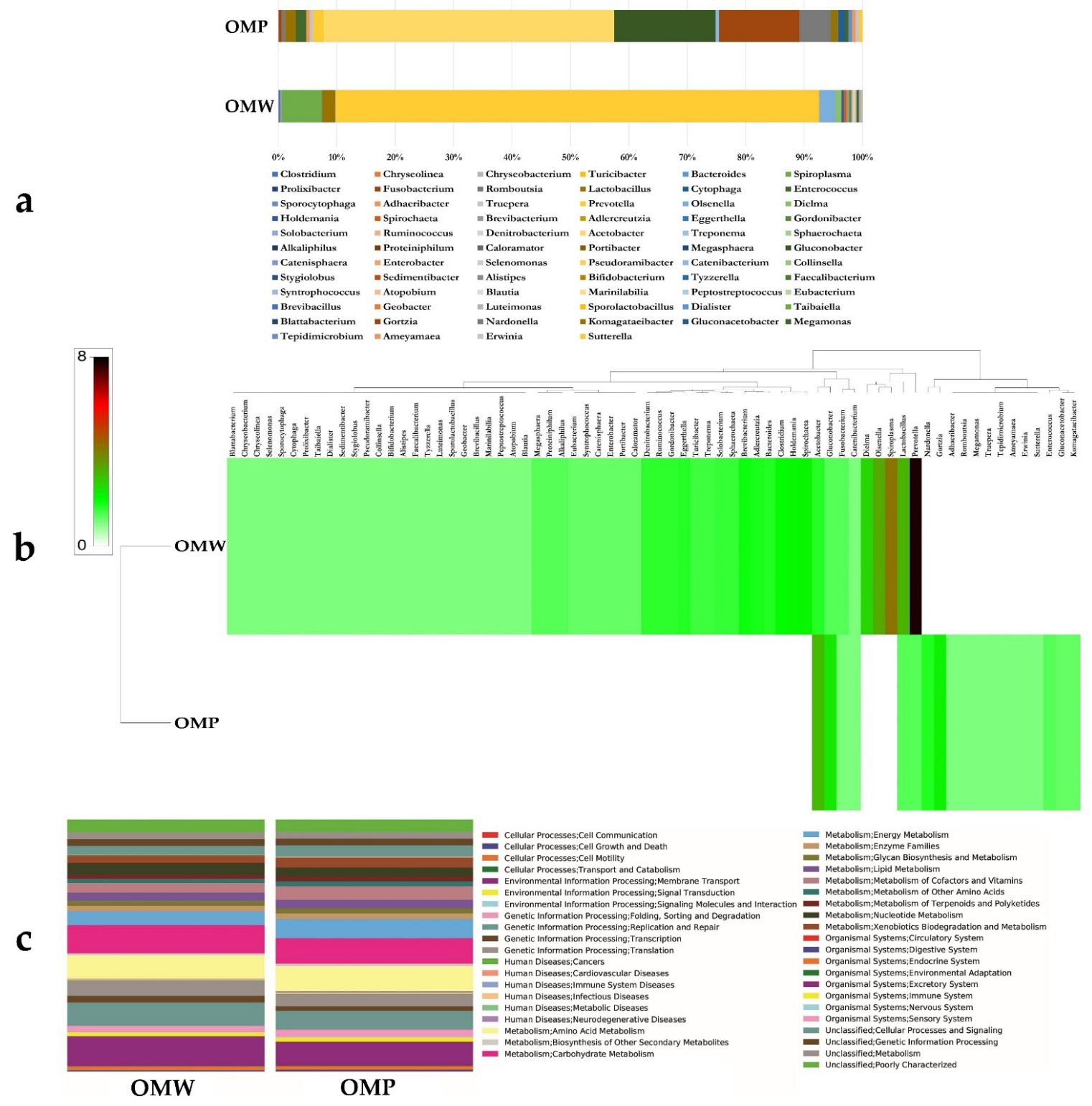

Figure 5. (a) Bar-chart (percentages) and (b) heat map (abundance) presenting uncultivable bacterial genera abundance within the OMP and OMW samples. Original data (Supplementary Material S3) unit is the number of bacterial genera in to OMW and OMP samples but was transformed by Primer-e program with Euclidean similarity and forth root transformation during heat-map producing. (c) PICRUSt classification of OMW and OMP functional category abundance.

Supplementary Material S1 contains heat-maps of the detailed bacterial classification of OMW and OMP including the phylum, class, order, family, genus and species of bacteria. Indeed, 4 Prevotella species (Prevotella oris, Prevotella stercorea, Prevotella genomo sp. and Prevotella albensis) and 1 Spiroplasma sp. prevailed the OMW. Other than that, Acetobacter ghanensis and Gortzia infectiva species prevailed the OMP (Supplementary Material S1).

Bacterial functions in OMW are very similar to those of OMP (Figure 5c). They are divided into 7 categories: cellular processes, organismal systems, metabolism, genetic information processing, environmental information processing, human diseases and few unclassified functions. The main bacterial functions were dedicated to the carbohydrate metabolism $(10.7 \%)$, the amino acid metabolism $(9.6 \%)$, and the energy metabolism (6.6\%). Otherwise, a considerable percentage $(12.5 \%)$ was attributed to the categories of environmental information processing and human diseases (Figure $5 \mathrm{c}$ ). 


\subsection{Genus Level and Metagenomics Analysis of Indigenous Fungal Communities in OMW and OMP Samples}

The fungal genera composition of OMW and OMP was described in Figure 6a. It clearly showed the profusion of 4 fungal genera named Nakazawaea, Saccharomyces, Lachancea and Candida in both OMW and OMP and that the fungal genera abundance was much higher in the OMP sample than the OMW sample. The obtained results also demonstrated that almost 35\% of fungal genera were unclassified (Figure 6a). Genome sequencing results presented in the Supplementary Material S2 showed that both OMW and OMP fungal diversity derived from the phylum Ascomycota and families of Pichiaceae and Saccharomycetaceae (Supplementary Material S2). Figure 6b showed that the OMP encompassed 36 different fungal genera and the OMW included 30 diverse fungal genera. These 2 related niches share in common 16 fungal genera, with Nakazawaea molendini-olei being the most abundant genus in both OMP and OMW (Figure $6 \mathrm{~b}$ and Supplementary Material S2). The remaining OMW fungal genera existed in small amounts as clearly shown in Figure 6b. Besides the Nakazawaea molendini-olei, three other fungal species named Saccharomyces cerevisiae, Lachancea fermentati and Candida diddensiae existed generously in OMP (Figure 6b, Supplementary Material S2).

OMW

OMP

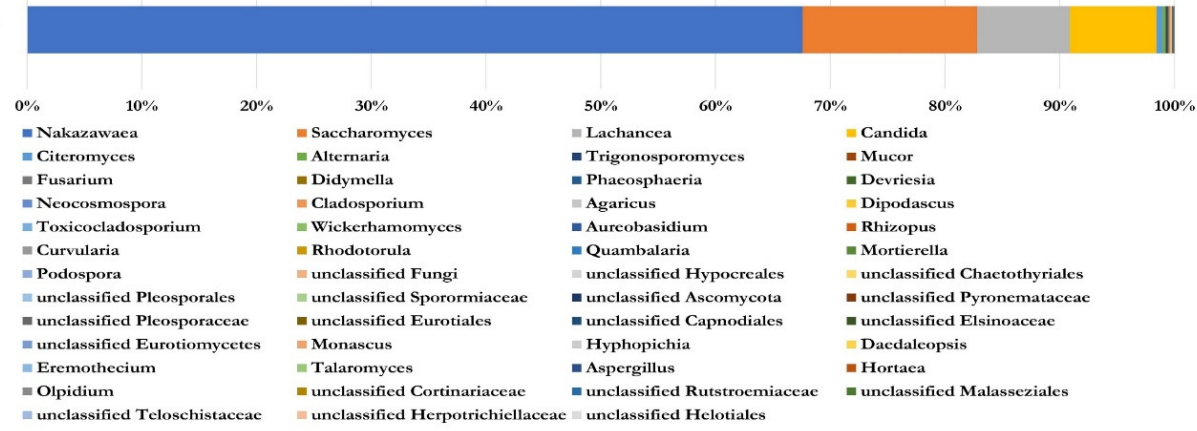

a

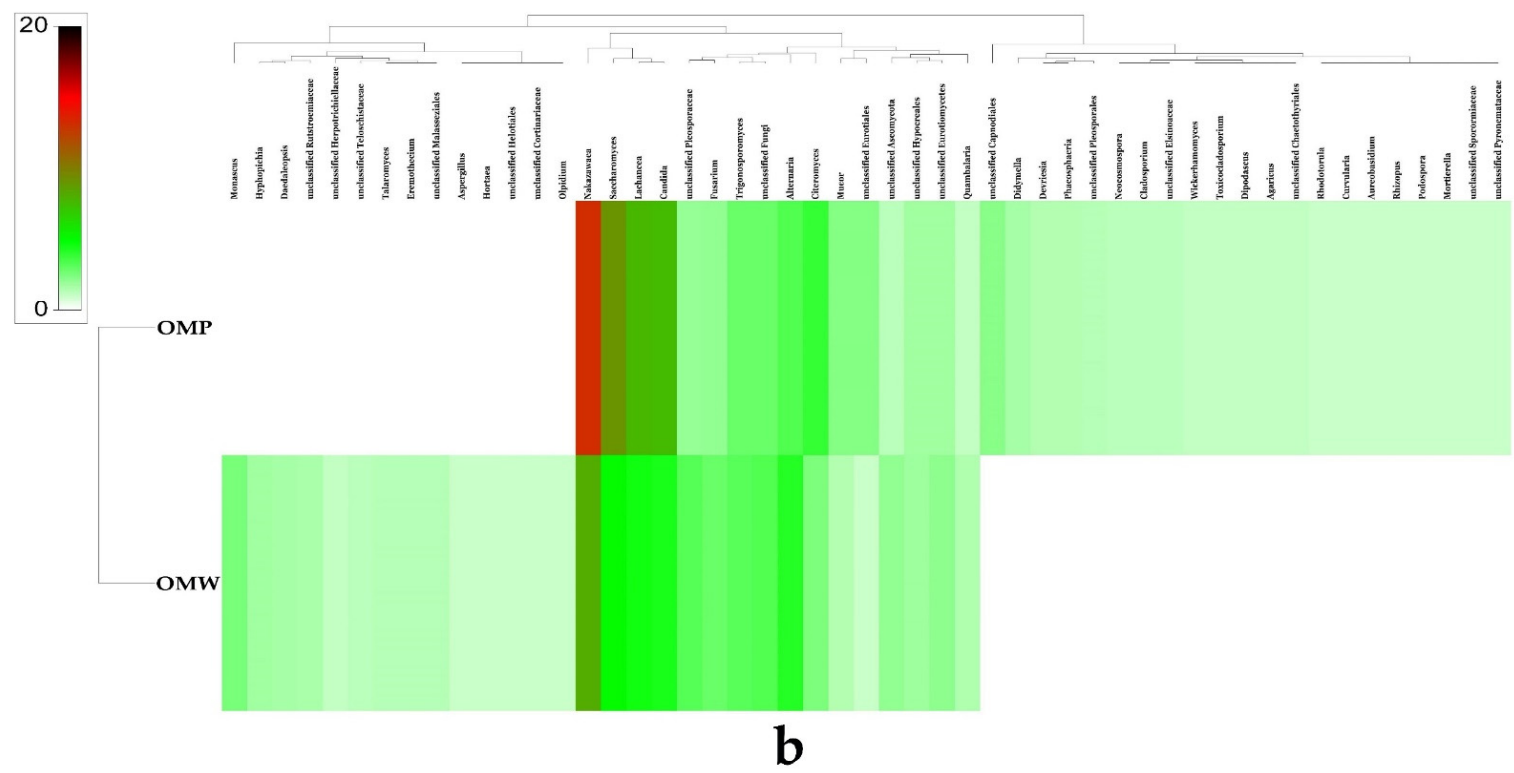

Figure 6. (a) Bar-chart (percentages) and (b) heat map (abundance) presenting uncultivable fungal genera within the OMP and OMW samples. Original data Supplementary Material S4 unit is the number of fungal genera in to OMW and OMP samples but was transformed by Primer-e program with Euclidean similarity and forth root transformation during heat-map producing. 


\section{Discussion}

Olive oil production is a staple agricultural and economic field in the Mediterranean countries. Solid (OMP) and liquid (OMW) wastes are composed of several organic and inorganic compounds, they contain high chemical oxygen demand (COD), biochemical oxygen demand (BOD) and heavy metals [7,31].

One of the most conventional treatment technologies is the disposal of OMW in evaporative ponds due to its simple and low-cost construction process [32]. The results from Figure 2 clearly showed the drawbacks of the use of uncontrolled evaporation ponds. Multiple insects and animals skeletons were stuck in the vicinity and inside the OMW ponds. This is confirmed by Michael et al. [24] who mentioned that evaporation ponds could reduce the amount of water and not the toxicity of OMW. Moreover, Lee et al. [18] indicated that the distinct and unpleasant odors derived from the evaporative ponds, attract insects during the processes of the by-products decomposition.

The analysis of the toxicity level of OMW, allowed us to detect the presence of various heavy metals (HMs) in 11 sampling sites situated within and around the OMW evaporation ponds of Agareb and Cherarda. We divided our results into 4 groups based on the HMs concentrations and presence or absence in the sample: (i) major metals $(\mathrm{Ca}, \mathrm{K}, \mathrm{Al}, \mathrm{Fe}, \mathrm{Mg}$, $\mathrm{Na}$ and $\mathrm{Sr}$ ), (ii) minor metals ( $\mathrm{Mn}, \mathrm{Ba}, \mathrm{Zn}, \mathrm{Rb}, \mathrm{Li}, \mathrm{Cr}, \mathrm{Cu}, \mathrm{Ni}, \mathrm{As}, \mathrm{Co}, \mathrm{Pb}$ and $\mathrm{Sn}$ ), (iii) metals found in only one sample each were Ag and Se, (iv) and lastly metals not detected in either OMW or OMP samples were $\mathrm{Cd}, \mathrm{Hg}$ and Mo. Mineral salts such as $\mathrm{Na}, \mathrm{Mg}$ and $\mathrm{K}$ were considered beneficial when spreading OMW in the agricultural soils as previously reported by multiple researchers [16,33]. Additionally, metal cations such as $\mathrm{Al}, \mathrm{Fe}, \mathrm{Mn}$, and $\mathrm{Ni}$ could be beneficial when present in modest concentrations. However, they became dangerous when they exist in high concentrations [34]. Pb, Cu, Cr, As, $\mathrm{Hg}$, and $\mathrm{Cd}$ could inhibit certain indigenous microbes' functions or cause environmental problems even at small concentrations [35]. Taken together, it is clear that OMW uncontrolled discharge is risky to the ecosystem especially that it is generated in huge amounts for a short period $[1,36,37]$.

LC-HRMS analysis of OMW and OMP samples revealed multiple secondary metabolites endowed with several biotechnological functions, but also, with harmful effects to humans or to the environment. For example, gallic acid was classified as a teratogen and mutagen [38], scoparone is an immunosuppressive agent [39,40], and stigmasterol is responsible for cardiac injury and it promotes mortality [41]. Moreover, two environmentally harmful secondary metabolites were detected in both OMW and OMP. The ferulic acid responsible for the initiation of the virulence region of Agrobacterium tumefaciens, inducing it to infect plant cells [42] and the maslinic acid having weak inhibitory activities on cytochrome P450 (CYP) isoforms, suggesting that it has low potential to cause possible toxicity and drug interactions involving CYP enzymes [43,44].

Multiple technologies have been investigated to treat the olive mill discharges $[5,13,32,45]$. Particularly, bioremediation was often used in toxicity alleviation or pathogens inhibition by either applying external [22] or indigenous microbiota [27]. In the present study, we conducted an in-depth work on bacteria and fungal species residing within OMW and OMP using culture-independent approaches. Such indigenous microbiota could be further exploited in the remediation of OMW and OMP toxic wastes. For instance, we have implemented the metagenomics approach to identify and elucidate the role of the detected microbiota. Other researchers have used the DNA high-throughput sequencing and omics technologies to identify microbial communities and explain their mechanisms of OMW degradation $[25,26,46]$.

We investigated the phyla, classes, orders, families, genera and species of bacteria and fungi inhabiting OMW and OMP evaporation ponds. Our results indicated that the bacterial diversity in OMW is larger than that of OMP. Furthermore, the most abundant phyla existing in OMW were Bacteroidetes, Tenericutes, Actinobacteria and Firmicutes; and in OMP Proteobacteria phylum was dominating. Previous studies have reported that the main phyla revealed using high-throughput sequencing technologies in different organic wastes including OMW are members of Bacteroidetes, Actinobacteria, Proteobacteria 
and Firmicutes [4,26,47-49]. OMW's dominating families were those of Prevotellaceae, Spiroplasmataceae, Atopobiaceae, Lactobacillaceae and Erysipelotrichaceae. Whereas, OMP's most abundant families were Acetobacteriaceae and Holosporaceae. Interestingly, Kavroulakis and Ntougias [50] have found that the Prevotellaceae family existed in the OMW because of the anaerobic condition created in case of harvested olive accumulation (before olive oil extraction). Additionally, the Spiroplasmataceae family was mainly represented by the Spiroplasma sp., which was reported to contribute to the degradation of multiple categories of organic wastes as mentioned by Gupta and Garg [51]. The non- $\mathrm{H}_{2}$ producing bacteria Olsenella sp. was abundantly present in the OMW, and it was identified to turn hexose into propionic acid and acetic acid in food wastes [52]. Other than that, previous works proved the major role of indigenous microbiota in the degradation of OMW hazardous components during the composting process [18,53-55]. Lastly, PICRUSt was used to identify gene function abundance based on the sequence similarity with the input marker gene. The major bacterial functions were dedicated to crucial functions such as amino acid, carbohydrate and energy metabolisms. Similar findings indicated that bacterial genetic composition was mainly devoted to the vital bacterial functions [28,56]. Surprisingly, bacterial functions of OMW and OMP involved human diseases (cardiovascular, infectious, and metabolic diseases). Similarly, Doula et al. [57] cited that intense OMW discharge near urban areas affects the water surface leading to human health problems.

Concerning the fungal microbiota, we demonstrated that the fungal communities of OMW and OMP were very similar to each other. They were mainly composed of Ascomycota, Basidiomycota and unclassified fungi. These findings accorded with the fungal sequences deposited in GenBank, which indicated that Ascomycota, Basidiomycota and unclassified fungi were mainly abundant in the OMW environments [25]. The predominant species in our study were Nakazawaea molendini-olei, Saccharomyces cerevisiae, Lachancea fermentati, Candida diddensiae, Candida adriatica and Alternaria sp. Many of them were widespread in olive fruits, olive oil, or olive mill solid and liquid wastes derived from several countries including Morocco and Italy [58-60]. Researchers proved that yeasts such as Saccharomyces and Candida, and fungi such as Lachancea, Alternaria and Pichia were able to reduce multiple recalcitrant compounds, thus contributing to the bioremediation of the olive mill discharges [61-63].

\section{Conclusions}

The OMW effluent discharge is continuously rising with the rise of the global demand for olive oil. Our study provided valuable information about the OMW and OMP toxicity levels with the existence of several heavy metals in the evaporation ponds of Agareb and Cherarda, which constitute an extreme threat to our ecosystem. Despite these findings, the metagenomic identification of the indigenous microbial community, allowed us to deduce their prospective role in alleviating the toxicity of olive mill by-products. In perspective, researchers and olive oil industries are considering working on specified and lucrative treatment methods to manage these wastes.

Supplementary Materials: The following are available online at https: / www.mdpi.com/article / 10.3390/app11115131/s1, Table S1: LCMS analysis results of OMW. Table S2: LCMS analysis results of OMP., Table S3: ICP-OES analysis and describing heavy metal composition. Supplementary Material S1: Different taxonomical levels of bacteria from OMW and OMP. Supplementary Material S2: Different taxonomical levels of fungi from OMW and OMP. Supplementary Material S3: Bacterial genera numbers in OMW and OMP samples. Supplementary Material S4. Fungal genera numbers in OMW and OMP samples.

Author Contributions: Conceptualization, H.B.S., A.C.B., A.K., L.L., F.N.A. and L.B.; methodology, L.B.; software, A.C.B., M.E.R.; validation, L.B.; formal analysis, A.C.B., M.E.R., L.B.; investigation, H.B.S., A.C.B., L.L., L.B.; resources, A.V. and L.B.; data curation, A.C.B.; writing-original draft preparation, H.B.S. and L.B.; writing-review and editing, H.B.S., L.B., M.E.R. and A.C.B.; visualization, L.L.; supervision, L.B.; project administration, L.B.; funding acquisition, T.O. and L.B. All authors have read and agreed to the published version of the manuscript. 
Funding: This research received no external funding.

Institutional Review Board Statement: Not applicable.

Informed Consent Statement: Not applicable.

Conflicts of Interest: The authors declare no conflict of interest.

\section{References}

1. Gomez-Munoz, B.; Hatch, D.J.; Bol, R.; Garcia-Ruiz, R. The compost of olive mill pomace: From a waste to a resource-environmental benefits of its application in olive oil groves. In Sustainable Development: Authoritative and Leading Edge Content for Environmental Management; Curkovic, S., Ed.; InTechOpen Ltd.: Rijeka, Croatia, 2012. [CrossRef]

2. Federici, E.; Massaccesi, L.; Pezzolla, D.; Fidati, L.; Montalbani, E.; Proietti, P.; Nasini, L.; Regni, L.; Scargetta, S.; Gigliotti, G. Short-term modifications of soil microbial community structure and soluble organic matter chemical composition following amendment with different solid olive mill waste and their derived composts. Appl. Soil Ecol. 2017, 119, 234-241. [CrossRef]

3. Piotrowska, A.; Rao, M.A.; Scotti, R.; Gianfreda, L. Changes in soil chemical and biochemical properties following amendment with crude and dephenolized olive mill waste water (OMW). Geoderma 2011, 161, 8-17. [CrossRef]

4. Tsiamis, G.; Tzagkaraki, G.; Chamalaki, A.; Xypteras, N.; Andersen, G.; Vayenas, D.; Bourtzis, K. Olive-mill wastewater bacterial communities display a cultivar specific profile. Curr. Microbiol. 2012, 64, 197-203. [CrossRef] [PubMed]

5. Doğan, K.; Sarıŏlu, A.; Coşkan, A. Contribution of green manure, Rhizobium and humic+ fulvic acid on recovering soil biologic activity of olive mill wastewater contaminated soil. Sci. Pap. A. Agron. 2016, 59, 63-68.

6. Meftah, O.; Guergueb, Z.; Braham, M.; Sayadi, S.; Mekki, A. Long term effects of olive mill wastewaters application on soil properties and phenolic compounds migration under arid climate. Agric. Water Manag. 2019, 212, 119-125. [CrossRef]

7. El-Bassi, L.; Azzaz, A.A.; Jellali, S.; Akrout, H.; Marks, E.A.N.; Ghimbeu, C.M.; Jeguirim, M. Application of olive mill waste-based biochars in agriculture: Impact on soil properties, enzymatic activities and tomato growth. Sci. Total Environ. 2021, 755, 142531. [CrossRef]

8. Milanović, V.; Osimani, A.; Cardinali, F.; Taccari, M.; Garofalo, C.; Clementi, F.; Ashoor, S.; Mozzon, M.; Foligni, R.; Canonico, L.; et al. Effect of inoculated Azotobacteria and Phanerochaete Chrysosporium on the composting of olive pomace: Microbial community dynamics and phenols evolution. Sci. Rep. 2019, 9, 16966. [CrossRef] [PubMed]

9. Ioannou-Ttofa, L.; Michael-Kordatou, I.; Fattas, S.C.; Eusebio, A.; Ribeiro, B.; Rusan, M.; Amer, A.R.B.; Zuraiqi, S.; Waismand, M.; Linder, C.; et al. Treatment efficiency and economic feasibility of biological oxidation, membrane filtration and separation processes, and advanced oxidation for the purification and valorization of olive mill wastewater. Water Res. 2017, 114, 1-13. [CrossRef]

10. Kontos, S.; Iakovides, I.; Koutsoukos, P.; Paraskeva, C. Isolation of purified high added value products from olive mill wastewater streams through the implementation of membrane technology and cooling crystallization process. Chem. Eng. Trans. 2016, 47, 337-342.

11. Chiavola, A.; Farabegoli, G.; Antonetti, F. Biological treatment of olive mill wastewater in a sequencing batch reactor. Biochem. Eng. J. 2014, 85, 71-78. [CrossRef]

12. Annab, H.; Fiol, N.; Villaescusa, I.; Essamri, A. A proposal for the sustainable treatment and valorisation of olive mill wastes. J. Environ. Chem. Eng. 2019, 7, 102803. [CrossRef]

13. Benamar, A.; Mahjoubi, F.Z.; Barka, N.; Kzaiber, F.; Boutoial, K.; Ali, G.A.M.; Oussama, A. Olive mill wastewater treatment using infiltration percolation in column followed by aerobic biological treatment. SN Appl. Sci. 2020, 2, 655. [CrossRef]

14. Yay, A.S.E.; Oral, H.V.; Onay, T.T.; Yenigün, O. A study on olive oil mill wastewater management in Turkey: A questionnaire and experimental approach. Resour. Conserv. Recycl. 2012, 60, 64-71.

15. Poerschmann, J.; Weiner, B.; Baskyr, I. Organic compounds in olive mill wastewater and in solutions resulting from hydrothermal carbonization of the wastewater. Chemosphere 2013, 92, 1472-1482. [CrossRef] [PubMed]

16. Aharonov-Nadborny, R.; Tsechansky, L.; Raviv, M.; Graber, E.R. Impact of spreading olive mill waste water on agricultural soils for leaching of metal micronutrients and cations. Chemosphere 2017, 179, 213-221. [CrossRef]

17. Benavente, V.; Fullana, A.; Berge, N.D. Life cycle analysis of hydrothermal carbonization of olive mill waste: Comparison with current management approaches. J. Clean. Prod. 2017, 142, 2637-2648. [CrossRef]

18. Lee, Z.S.; Chin, S.Y.; Lim, J.W.; Witoon, T.; Cheng, C.K. Treatment technologies of palm oil mill effluent (POME) and olive mill wastewater (OMW): A brief review. Environ. Technol. Innov. 2019, 15, 100377. [CrossRef]

19. Amor, C.; Lucas, M.S.; Garcia, J.; Dominguez, J.R.; De Heredia, J.B.; Peres, J.A. Combined treatment of olive mill wastewater by Fenton's reagent and anaerobic biological process. J. Environ. Sci. Health A 2015, 50, 161-168. [CrossRef]

20. Frascari, D.; Bacca, A.E.M.; Zama, F.; Bertin, L.; Fava, F.; Pinelli, D. Olive mill wastewater valorisation through phenolic compounds adsorption in a continuous flow column. Chem. Eng. J. 2016, 283, 293-303. [CrossRef]

21. Reis, P.M.; Martins, P.J.M.; Martins, R.C.; Gando-Ferreira, L.M.; Quinta-Ferreira, R.M. Integrating Fenton's process and ion exchange for olive mill wastewater treatment and iron recovery. Environ. Technol. 2018, 39, 308-316. [CrossRef]

22. Sáez, J.A.; Pérez-Murcia, M.D.; Vico, A.; Martínez-Gallardo, M.R.; Andreu-Rodriguez, F.J.; López, M.J.; Bustamante, M.A.; Sanchez-Hernandez, J.C.; Moreno, J.; Moral, R. Olive mill wastewater-evaporation ponds long term stored: Integrated assessment of in situ bioremediation strategies based on composting and vermicomposting. J. Hazard. Mat. 2021, 402, 123481. [CrossRef] 
23. Cassano, A.; Conidi, C.; Drioli, E. Comparison of the performance of UF membranes in olive mill wastewaters treatment. Water Res. 2011, 45, 3197-3204. [CrossRef]

24. Michael, I.; Panagi, A.; Ioannou, L.A.; Frontistis, Z.; Fatta-Kassinos, D. Utilizing solar energy for the purification of olive mill wastewater using a pilot-scale photocatalytic reactor after coagulation-flocculation. Water Res. 2014, 60, 28-40. [CrossRef]

25. Ntougias, S.; Bourtzis, K.; Tsiamis, G. The Microbiology of Olive Mill Wastes. Available online: https://www.hindawi.com/ journals/bmri/2013/784591/ (accessed on 29 October 2020).

26. Tortosa, G.; Castellano-Hinojosa, A.; Correa-Galeote, D.; Bedmar, E.J. Evolution of bacterial diversity during two-phase olive mill waste ("Alperujo") composting by 16S-rRNA gene pyrosequencing. Bioresour. Technol. 2017, 224, 101-111. [CrossRef]

27. Martínez-Gallardo, M.R.; López, M.J.; López-González, J.A.; Jurado, M.M.; Suárez-Estrella, F.; Pérez-Murcia, M.D.; Sáez, J.A.; Moral, R.; Moreno, J. Microbial communities of the olive mill wastewater sludge stored in evaporation ponds: The resource for sustainable bioremediation. J. Environ. Manag. 2021, 279, 111810. [CrossRef]

28. Mefteh, F.; Chenari Bouket, A.; Daoud, A.; Luptakova, L.; Alenezi, F.; Gharsallah, N.; Lassaad, B. Metagenomic insights and genomic analysis of phosphogypsum and its associated plant endophytic microbiomes reveals valuable actors for waste bioremediation. Microorganisms 2019, 7, 382. [CrossRef]

29. Daoud, A.; Mefteh, F.; Mnafgui, K.; Turki, M.; Jmal, S.; Amar, R.; Ayadi, F.; ElFeki, A.; Abid, L.; Rateb, M.; et al. Cardiopreventive effect of ethanolic extract of date palm pollen against isoproterenol induced myocardial infarction in rats through the inhibition of the angiotensin-converting enzyme. Exp. Toxicol. Pathol. 2017, 69. [CrossRef] [PubMed]

30. Douglas, G.M.; Beiko, R.G.; Langille, M.G.I. Predicting the functional potential of the microbiome from marker genes using PICRUSt. Methods Mol. Biol. 2018, 1849, 169-177. [CrossRef] [PubMed]

31. Karpouzas, D.G.; Ntougias, S.; Iskidou, E.; Rousidou, C.; Papadopoulou, K.K.; Zervakis, G.I.; Ehaliotis, C. Olive mill wastewater affects the structure of soil bacterial communities. Appl. Soil Ecol. 2010, 45, 101-111. [CrossRef]

32. Alfano, G.; Lustrato, G.; Lima, G.; Ranalli, G. Present and Future Perspectives of Olive Residues Composting in the Mediterranean Basin (CompMed). Dynamic Soil, Dynamic Plant; Global Science Books: Isleworth, UK, 2009; pp. 39-56.

33. Tajini, F.; Ouerghi, A.; Hosni, K. Effect of irrigation with olive-mill waste-water on physiological and biochemical parameters as well as heavy-metal accumulation in common bean (Phaseolus vulgaris L.). J. New Sci. 2019, 66, 6.

34. Martinez-Garcia, G.; Bachmann, R.T.; Williams, C.J.; Burgoyne, A.; Edyvean, R.G. Olive oil waste as a biosorbent for heavy metals. Int. Biodeter. Biodegrad. 2006, 58, 231-238. [CrossRef]

35. Guo, Q.; Majeed, S.; Xu, R.; Zhang, K.; Kakade, A.; Khan, A.; Hafeez, F.Y.; Mao, C.; Liu, P.; Li, X. Heavy metals interact with the microbial community and affect biogas production in anaerobic digestion: A review. J. Environ. Manag. 2019, 240, 266-272. [CrossRef]

36. Vuppala, S.; Bavasso, I.; Stoller, M.; Di Palma, L.; Vilardi, G. Olive mill wastewater integrated purification through pre-treatments using coagulants and biological methods: Experimental, modelling and scale-up. J. Clean. Prod. 2019, 236, 117622. [CrossRef]

37. El Hanandeh, A. Energy recovery alternatives for the sustainable management of olive oil industry waste in Australia: Life cycle assessment. J. Clean. Prod. 2015, 91, 78-88. [CrossRef]

38. Chanwitheesuk, A.; Teerawutgulrag, A.; Kilburn, J.D.; Rakariyatham, N. Antimicrobial gallic acid from Caesalpinia mimosoides Lamk. Food Chem. 2007, 100, 1044-1048. [CrossRef]

39. Huang, H.-C.; Lee, C.-R.; Weng, Y.-I.; Lee, M.-C.; Lee, Y.-T. Vasodilator effect of Scoparone (6,7-Dimethoxycoumarin) from a Chinese herb. Eur. J. Pharmacol. 1992, 218, 123-128. [CrossRef]

40. Huei-Chen, H.; Shu-Hsun, C.; Chao, P.-D.L. Vasorelaxants from Chinese herbs, Emodin and Scoparone, possess immunosuppressive properties. Eur. J. Pharmacol. 1991, 198, 211-213. [CrossRef]

41. Tao, C.; Shkumatov, A.A.; Alexander, S.T.; Ason, B.L.; Zhou, M. Stigmasterol accumulation causes cardiac injury and promotes mortality. Commun. Biol. 2019, 2, 1-10. [CrossRef]

42. Kalogeraki, V.S.; Zhu, J.; Eberhard, A.; Madsen, E.L.; Winans, S.C. The phenolic vir gene inducer ferulic acid is O-Demethylated by the virH2 protein of an Agrobacterium tumefaciens Ti Plasmid. Mol. Microbiol. 1999, 34, 512-522. [CrossRef]

43. Lozano-Mena, G.; Sánchez-González, M.; Juan, M.E.; Planas, J.M. Maslinic Acid, a natural phytoalexin-type triterpene from olives-a promising nutraceutical? Molecules 2014, 19, 11538-11559. [CrossRef] [PubMed]

44. Mokhtari, K.; Rufino-Palomares, E.E.; Pérez-Jiménez, A.; Reyes-Zurita, F.J.; Figuera, C.; García-Salguero, L.; Medina, P.P.; Peragón, J.; Lupiáñez, J.A. Maslinic Acid, a triterpene from olive, affects the antioxidant and mitochondrial status of B16F10 melanoma cells grown under stressful conditions. Evid-Based Compl. Alt. Med. 2015, 2015. [CrossRef] [PubMed]

45. Hodaifa, G.; Ochando-Pulido, J.M.; Rodriguez-Vives, S.; Martinez-Ferez, A. Optimization of continuous reactor at pilot scale for olive-oil mill wastewater treatment by fenton-like process. Chem. Eng. J. 2013, 220, 117-124. [CrossRef]

46. Hultman, J.; Kurola, J.; Rainisalo, A.; Kontro, M.; Romantschuk, M. Utility of molecular tools in monitoring large scale composting. In Microbes at Work: From Wastes to Resources; Insam, H., Franke-Whittle, I., Goberna, M., Eds.; Springer: Berlin/Heidelberg, Germany, 2010; pp. 135-151.

47. Storey, S.; Chualain, D.N.; Doyle, O.; Clipson, N.; Doyle, E. Comparison of bacterial succession in green waste composts amended with inorganic fertilizer and wastewater treatment plant sludge. Bioresour. Technol. 2015, 179, 71-77. [CrossRef]

48. Morillo, J.A.; Aguilera, M.; Antízar-Ladislao, B.; Fuentes, S.; Ramos-Cormenzana, A.; Russell, N.J.; Monteoliva-Sánchez, M. Molecular microbial and chemical investigation of the bioremediation of two-phase olive mill waste using laboratory-scale bioreactors. Appl. Microbiol. Biotechnol. 2008, 79, 309-317. [CrossRef] [PubMed] 
49. Neher, D.A.; Weicht, T.R.; Bates, S.T.; Leff, J.W.; Fierer, N. Changes in bacterial and fungal communities across compost recipes, preparation methods, and composting times. PLOS ONE 2013, 8, e79512. [CrossRef] [PubMed]

50. Kavroulakis, N.; Ntougias, S. Bacterial and $\beta$-proteobacterial diversity in Olea europaea var. mastoidis and O. europaea var. koroneiki generated olive mill wastewaters: Influence of cultivation and harvesting practice on bacterial community structure. World J. Microbiol. Biotechnol. 2011, 27, 57-66. [CrossRef]

51. Gupta, R.; Garg, V.K. 5-Vermitechnology for organic waste recycling. In Current Developments in Biotechnology and Bioengineering; Wong, J.W.-C., Tyagi, R.D., Pandey, A., Eds.; Elsevier: Amsterdam, The Netherlands, 2017; pp. 83-112.

52. Jung, J.-H.; Sim, Y.-B.; Baik, J.-H.; Park, J.-H.; Kim, S.-H. High-rate mesophilic hydrogen production from food waste using hybrid immobilized microbiome. Bioresour. Technol. 2021, 320, 124279. [CrossRef] [PubMed]

53. Federici, E.; Pepi, M.; Esposito, A.; Scargetta, S.; Fidati, L.; Gasperini, S.; Cenci, G.; Altieri, R. Two-phase olive mill waste composting: Community dynamics and functional role of the resident microbiota. Bioresour. Technol. 2011, 102, 10965-10972. [CrossRef]

54. Chowdhury, A.K.M.M.B.; Akratos, C.S.; Vayenas, D.V.; Pavlou, S. Olive mill waste composting: A review. Int. Biodeterior. Biodegrad. 2013, 85, 108-119. [CrossRef]

55. Agnolucci, M.; Cristani, C.; Battini, F.; Palla, M.; Cardelli, R.; Saviozzi, A.; Nuti, M. Microbially-enhanced composting of olive mill solid waste (wet husk): Bacterial and fungal community dynamics at industrial pilot and farm level. Bioresour. Technol. 2013, 134, 10-16. [CrossRef]

56. Slama, H.; Cherif-Silini, H.; Chenari Bouket, A.; Qader, M.; Silini, A.; Yahiaoui, B.; Alenezi, F.; Luptakova, L.; Triki, M.; Vallat, A.; et al. Screening for Fusarium antagonistic bacteria from contrasting niches designated the endophyte Bacillus halotolerans as plant warden against Fusarium. Front. Microbiol. 2019, 9. [CrossRef] [PubMed]

57. Doula, M.K.; Moreno-Ortego, J.L.; Tinivella, F.; Inglezakis, V.J.; Sarris, A.; Komnitsas, K. Olive mill waste: Recent advances for the sustainable development of olive oil industry. In Olive Mill Waste: Recent Advances for Sustainable Management; Galanakis, C.M., Ed.; Academic Press: Cambridge, MA, USA, 2017; pp. 29-56.

58. Sassi, A.B.; Ouazzani, N.; Walker, G.M.; Ibnsouda, S.; El Mzibri, M.; Boussaid, A. Detoxification of olive mill wastewaters by Moroccan yeast isolates. Biodegradation 2008, 19, 337-346. [CrossRef] [PubMed]

59. Sinigaglia, M.; Di Benedetto, N.; Bevilacqua, A.; Corbo, M.R.; Capece, A.; Romano, P. Yeasts isolated from olive mill wastewaters from Southern Italy: Technological characterization and potential use for phenol removal. Appl. Microbiol. Biotechnol. 2010, 87, 2345-2354. [CrossRef] [PubMed]

60. Ciafardini, G.; Zullo, B.A. Use of selected yeast starter cultures in industrial-scale processing of brined taggiasca black table olives. Food Microbiol. 2019, 84, 103250. [CrossRef]

61. Bleve, G.; Lezzi, C.; Chiriatti, M.A.; D’Ostuni, I.; Tristezza, M.; Di Venere, D.; Sergio, L.; Mita, G.; Grieco, F. Selection of nonconventional yeasts and their use in immobilized form for the bioremediation of olive oil mill wastewaters. Bioresour. Technol. 2011, 102, 982-989. [CrossRef]

62. Jarboui, R.; Baati, H.; Fetoui, F.; Gargouri, A.; Gharsallah, N.; Ammar, E. Yeast performance in wastewater treatment: Case study of Rhodotorula mucilaginosa. Environ. Technol. 2012, 33, 951-960. [CrossRef]

63. Bevilacqua, A.; Cibelli, F.; Raimondo, M.L.; Carlucci, A.; Lops, F.; Sinigaglia, M.; Corbo, M.R. Fungal bioremediation of olive mill wastewater: Using a multi-step approach to model inhibition or stimulation. J. Sci. Food Agric. 2017, 97, 461-468. [CrossRef] 